be overlooked. Next to this probably the most important function of these classes is the formation of habits of ocular hygiene, and the influencing of pupils towards the choice of a vocation which will not make too great demands upon their vision.

Discussing the teachers, he considers much of the backwardness of the blind schools is due to the absence of special training of the teachers. These should have training in the psychology and education of the blind, and three or four years of successful experience with seeing children. Teachers of sight-saving classes are better provided for, since 1921 many courses of instruction have been given at various colleges, universities, and normal schools throughout the country.

$\mathrm{He}$ is insistent that his examination of this problem shows the need for experimentation and research. The field should be valuable to the research worker, as the majority of its problems are as yet untouched. He warns the authorities not " to expect bizarre and sensational results, and to regard research as a form of publicity rather than as a slow, diligent, and non-spectacular search for truth."

This book will be of value to all interested in the care of the blind, whether they be medical practitioners or laymen.

N. BISHOP HARMAN.

\title{
OBITUARY
}

\section{JOHN BOWRING LAWFORD}

THE death of Mr. Lawford, briefly alluded to in our last number, deprives British Ophthalmology of one of its outstanding members and his friends of a very lovable personality. Though he retired from practice rather more than four years ago, his interest in ophthalmology was as keen as ever, and his mental outlook still that of a young man. This journal will miss him sorely. Lawford was the son of Mr. Frederick Lawford, of Montreal, and was born there in 1858. Educated in that city and at McGill University, he graduated M.D., C.M. in 1879 and immediately sailed for London. Here he joined the school of St. Thomas's Hospital and took the M.R.C.S. in the same year. After holding the usual resident posts at St. Thomas's, he was for a time resident assistant at Bethlem Hospital. He next enrolled as a student at Moorfields, where he held the posts of house-surgeon and curator of the museum. Thence onwards ophthalmology claimed his chief interest. He passed the examination for F.R.C.S. Eng. in 1885, 


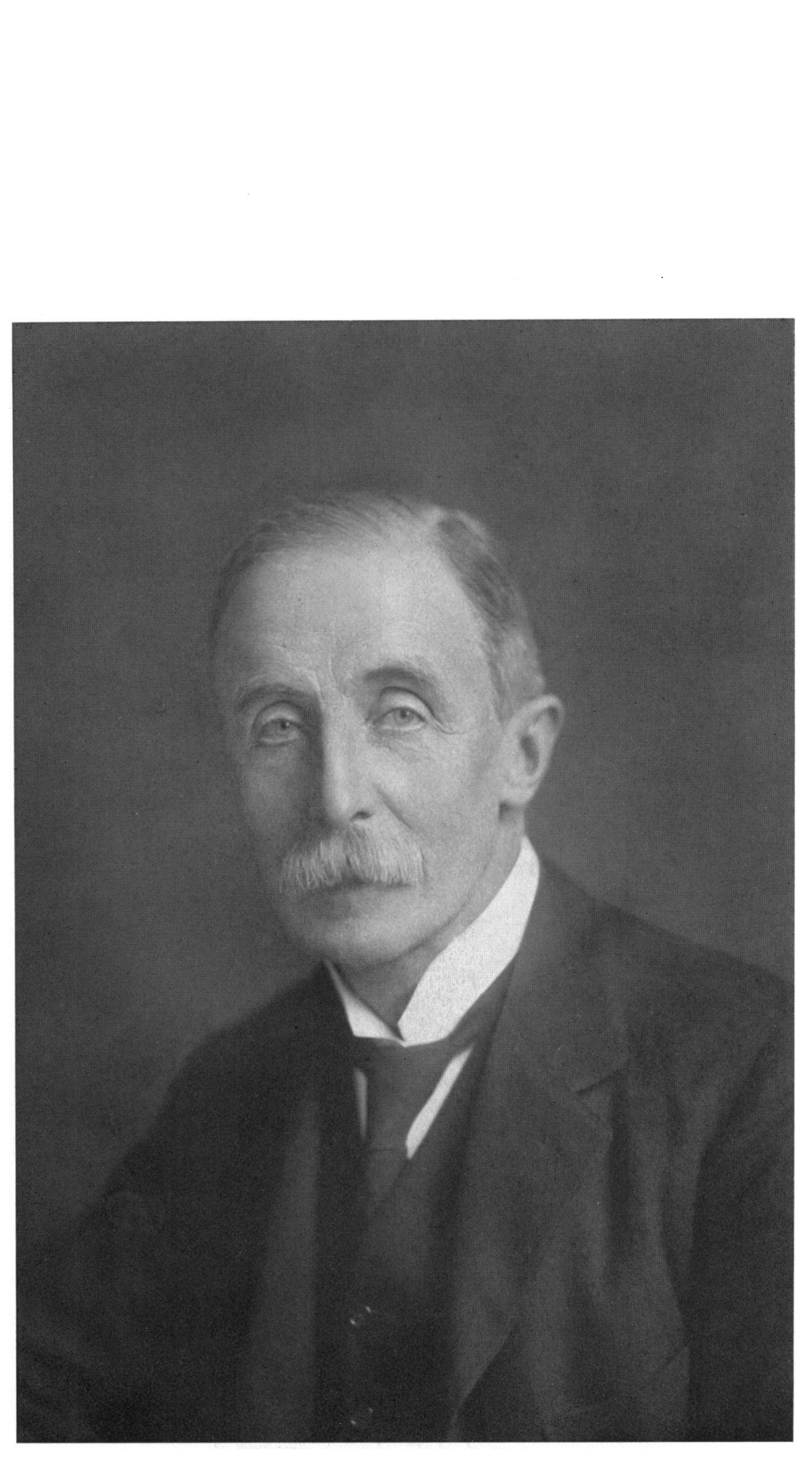


and in the following year was elected assistant ophthalmic surgeon to St. Thomas's ; his chief being the late Edward Nettleship. In 1890 he joined the honorary staff at Moorfields.

On the foundation of the Ophthalmological Society of the United Kingdom in 1880, Lawford became an original member; and from volume 2 to the last volume hardly a year passed without the transactions containing some contribution from his pen. In proposing a vote of thanks to Sir Arthur Keith for his Bowman Lecture at the jubilee of the Society, he recalled the fact that he was one of the few original members left who had sat at the feet of Sir William Bowman. The last time the writer met him was at the Annual Congress last year, which he attended in spite of the unsatisfactory state of his health.

The later volumes of the Ophthalmic Hospital Reports contain many papers by him from the time of his curatorship to the penultimate volume. Among these his papers on hereditary glaucoma are specially worthy of note.

Lawford became surgical secretary of the Ophthalmological Society in 1895, and held this post for the statutory period of three years. He served on the council and from 1906-1910 was treasurer of the Society. In 1911 he was elected President and chose as his presidential address the subject of inoculation treatment in diseases of the eye.

His long connexion with Nettleship had made him a master clinician. He was never tired of expatiating on the advantage it had been to him to have been trained by such an accurate observer and tireless worker. He assisted Nettleship in his private practice and was present to help at the extraction of $\mathrm{Mr}$. W. E. Gladstone's cataract. He wrote the obituary of his former chief for the Lancet, and contributed an admirable memoir of Nettleship to the memorial volume in the Treasury of Human Inheritance. This memoir was reprinted, by permission, in our pages, Vol. VII. Lawford was a member of the editorial staff of the Ophthalmic Review for many years, and acted as editor-inchief for two periods in the history of that journal. In our last number we tried to express the great debt which this journal has owed to him from its beginning.

As we mentioned in our annotation last month, Lawford was elected Chairman of the Editorial Committee of the Journal in 1916, and almost immediately became senior Managing Director of the Company, which post he resigned in 1926 . His previous experience as Editor of the Ophthalmic Review for many years was invaluable' to the Editorial Committee of which he was a very active member.

In later life Lawford did a great deal of notable public work. He was chairman of the Council of British Ophthalmologists 
and an active and energetic member of the Prevention of Blindness Committee, the Union of Counties Association for the Blind, and the National Lending Library for the Blind. With his colleague, the late Herbert Fisher, he took a large share in drawing up the certificate of blindness in connexion with the Blind Persons Act, and we know how much the members of the committee appreciated his services.

As an ophthalmic surgeon, Lawford was one of the most accomplished men of his time. His thorough training, coupled with high ideals and superlative conscientiousness, made his opinion on any ophthalmological subject always worthy of close attention. He conducted a large practice for many years, and both in private and hospital work made a host of friends and admirers, who were impressed by his obvious sincerity and his hatred of slackness and shoddy work of all kinds. He was an all-round man in his specialty. Gifted with marked manual dexterity, his operations were models of perfection. Never in a hurry; slow to change from established procedures to the latest " new thing" in treatment, he was, nevertheless, always up-to-date. The award of an Hon. LL.D. of McGill University in 1921 was a fitting honour for his Alma Mater to have bestowed on one of her most distinguished alumni; and it gave great satisfaction, not only to Lawford himself, but to all who knew him.

Among other honours accorded to him was one which he valued very highly, namely, the hon. membership of the Société française d'ophtalmologie. For years he was the principal liaison officer between French and British ophthalmology. His careful abstracts of papers from the Arch. d'ophtal. have been one of the most valuable features in our abstract section from the beginning.

In December last his health underwent a relapse, and it was thought prudent that he should give up all literary work for a time. This was obviously a grief to him. He wrote to announce the decision of his doctors and asked if any other reviewer could be found to take the Arch. d'ophtal. off his hands for a few months. It was characteristic of him that he retained the numbers which he had already received and had not been able to abstract, in the hope that he would be able to attend to such matters in the New Year.

Mr. Lawford was unmarried. For many years he made a home for his mother and sisters, first in London and afterwards in Ashtead in Surrey, where he died on January 3.

Sir John Parsons writes :-

Only those who came into intimate contact with Lawford in his work can fully realize the loss which he is to British Ophthalmology. 
He was quite indefatigable, and his conscience would not allow him to decline any task, however arduous or uncongenial, if he considered it his duty to undertake it. It is to be feared that some of us, his colleagues on the staff of this journal, at times took undue advantage of his ever-ready help. The chief characteristic of his work was its thoroughness and meticulous accuracy. In this, as in so many other ways, he reflected the virtues of his great master, colleague, and friend, Edward Nettleship. His quiet and unassuming manner masked for many the extent and value of his contributions to science; but these are enshrined in the Royal London Ophthalmic Hospital Reports, the Transactions of the Ophthalmological Society, and in the pages of our Journal, and their reliability is such that they are safe foundations for others to build upon.

He had several very serious illnesses which he faced with imperturbable courage, returning to his work at the earliest moment-“" baffled," perhaps,-but " only to fight better." As a personal friend he was the same quiet and undemonstrative individual, apparently shy and retiring, but with a backbone of resolution which was a sure support to all those on whom he conferred his friendship.

\section{NOTES}

Elsyngspital THE foundation of a hospital or rather almshouse for 100 blind persons in the year 1329 A.D. is a matter of some interest in the history of ophthalmology. It was due to the munificence of William Elsing, mercer, of London. Founded on the site of an ancient nunnery in Gayspur Lane, near London Wall, it was known by the above title, and afterwards as Sion College. When Elsing made his will in 1348 he confirmed the gift of certain tenements, rents, etc., in the parishes of St. Alphege and St. Mary, Aldermanbury. The hospital at first consisted of a custos and four secular priests; but in 1340 the founder obtained a licence from the Bishop of London with the assent of the Dean and Chapter of St. Paul's, to change the secular canons into canons regular of the order of St. Augustine. The bishop added an extra canon, making five in all.

The hospital was dissolved by Henry the Eighth.

Elsing's will was proved in the Court of Husting, of the City of London. The fact that Thomas Morstede, surgeon to Henry the Fifth, made bequests in his will in 1450 to this hospital makes one 